RESEARCH ARTICLE

\title{
Characterisation of bacterioplankton communities in the meltwater ponds of Bratina Island, Victoria Land, Antarctica
}

\author{
Stephen D.J. Archer, Ian R. McDonald, Craig W. Herbold \& Stephen C. Cary \\ International Centre for Terrestrial Antarctic Research, School of Science, University of Waikato, Hamilton, New Zealand
}

\author{
Correspondence: Stephen C. Cary, School \\ of Science, University of Waikato, Private Bag \\ 3105, Hamilton 3240, New Zealand. \\ Tel.: +64 7838 4593; \\ fax: +64-07-838-4324; \\ e-mail: caryc@waikato.ac.nz
}

Received 12 November 2013; revised 12 May 2014; accepted 17 May 2014.

DOI: 10.1111/1574-6941.12358

Editor: Johanna Laybourn-Parry

Keywords

Antarctic; planktonic; microorganism; community; meltwater.

\begin{abstract}
A unique collection of Antarctic aquatic environments (meltwater ponds) lies in close proximity on the rock and sediment-covered undulating surface of the McMurdo Ice Shelf, near Bratina Island (Victoria Land, Antarctica). During the 2009-10 mid-austral summer, sets of discrete water samples were collected across the vertical geochemical gradients of five meltwater ponds (Egg, P70E, Legin, Salt and Orange) for geochemical and microbial community structure analysis. Bacterial DNA fingerprints (using Automated Ribosomal Intergenic Spacer Analysis) statistically clustered communities within ponds based on ANOSIM $(R=0.766, P=0.001)$; however, one highly stratified pond (Egg) had two distinct depth-related bacterial communities $(R=0.975, P=0.008) .454$ pyrosequencing at three depths within Egg also identified phylum level shifts and increased diversity with depth, Bacteroidetes being the dominant phyla in the surface sample and Proteobacteria being dominant in the bottom two depths. BEST analysis, which attempts to link community structure and the geochemistry of a pond, identified conductivity and $\mathrm{pH}$ individually, and to a lesser extent $\mathrm{Ag}^{109}, \mathrm{NO}_{2}$ and $\mathrm{V}^{51}$ as dominant influences to the microbial community structure in these ponds. Increasing abundances of major halo-tolerant OTUs across the strong conductivity gradient reinforce it as the primary driver of community structure in this study.
\end{abstract}

\section{Introduction}

The Antarctic continent offers access to one of the most physically and chemically demanding environments on earth. Antarctic limnetic ecosystems (lakes and ponds), in particular, experience large fluctuations in temperature and light regimes and are characterised by steep chemical gradients, which greatly impact physiological adaptations and life cycle strategies (Wait et al., 2006). These ecosystems, scattered throughout the Antarctic continent and on the surrounding sea ice, provide an extraordinary and tractable opportunity to examine microbial distribution in distinct and environmentally extreme microenvironments. Of the thousands of lakes and ponds throughout Antarctica, most research has focused primarily on lakes due to their size, stability and influence on the surrounding terrestrial system (Craig et al., 1992; Bell \& LaybournParry, 1999; Bowman et al., 2000; Pearce et al., 2003; Taton et al., 2003). However, due to their smaller size, ponds can be more susceptible to seasonal (and global) climatic changes, while offering easy access to a broad range of unique pond-specific geochemical conditions.

During the peak of the Antarctic summer up to $20 \%$ of the McMurdo Ice Shelf (MIS) in southern Victoria Land is covered with meltwater ponds of various sizes, making them a dominant environment in this area (De Mora et al., 1994). The ponds surrounding Bratina Island on the MIS (Fig. 1) provide a cross-section of the many geochemistries found in aquatic systems throughout Antarctica (Cowan \& Tow, 2004). Their existence is dependent on the short period, at the peak of summer, when liquid water from local ice melt collects in the depressions of the rugged landscape of the MIS replenishing pre-existing ponds and forming new ones (Howard-Williams \& Hawes, 2005). Marine-derived surface sediments and aerosols, as well as seawater trapped in tide cracks across the ice shelf, provide multiple variable inputs of dissolved salts into ponds. The fine balance between water and salt 


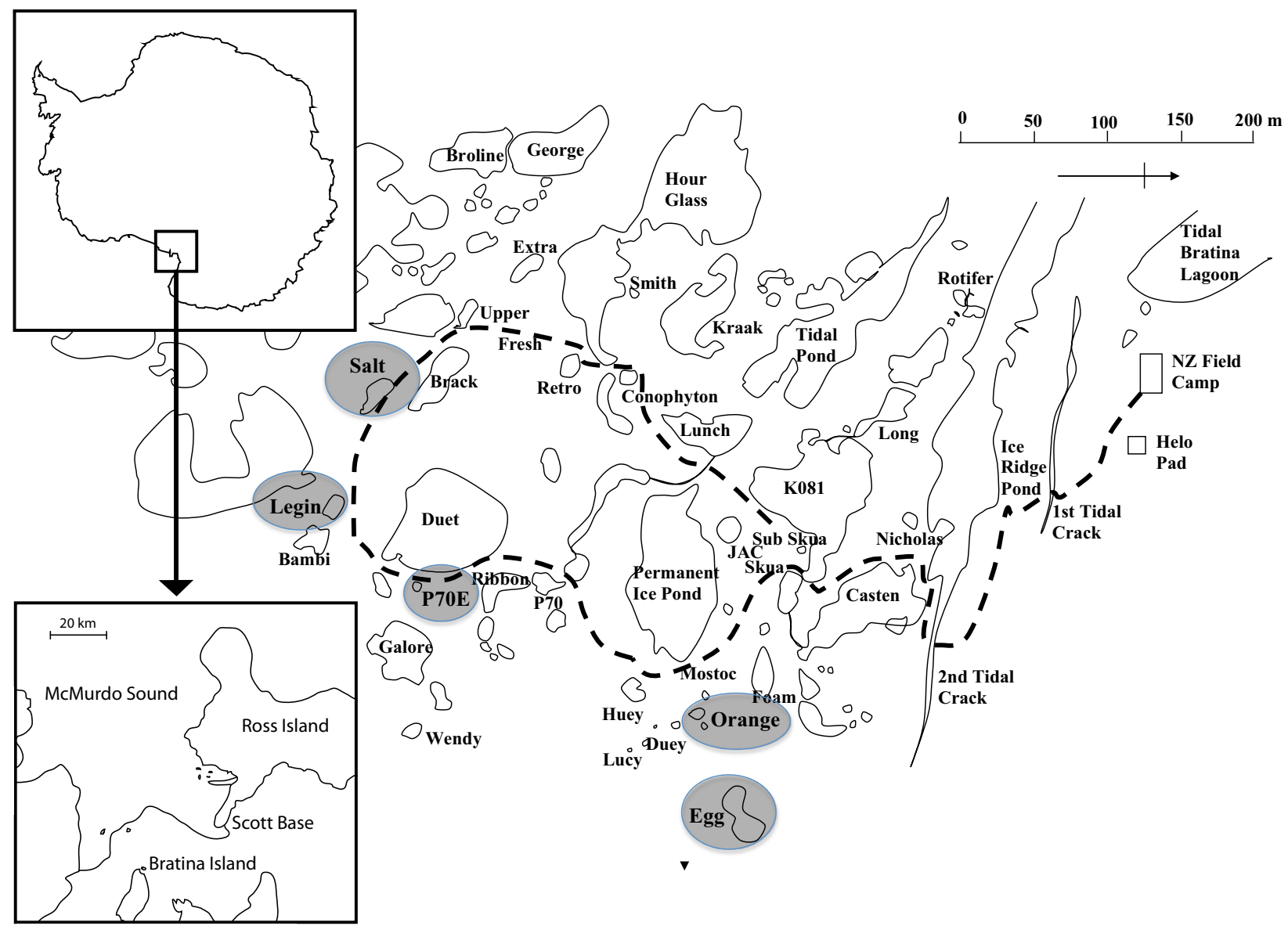

Fig. 1. Map of the MIS Ponds, based on an original map produced by New Zealand Department of Land and Surveys, 1991. Ponds circled were used in this study.

input and evaporation leads to both inter and intraseasonal variation of physicochemistry within a pond (Laybourn-Parry et al., 2002) and variable chemistries between ponds. Ponds in close proximity (metres apart) can vary greatly in size (one to several hundred square metres), depth $(<1 \mathrm{~m}$ to around $4 \mathrm{~m}$ ) and age (1 to at least 30 years old) (Gibson et al., 2006), as well as in metal concentrations, salinity (Schmidt et al., 1991; Matsumoto et al., 1992), pH and dissolved oxygen (Koob \& Leister, 1972). The water column within some ponds can be highly stratified, with a unique brine geochemistry derived from the freeze concentration of dissolved salts layering the bottom and newer meltwater input layering the surface. Oxygen, derived from Cyanobacteria dominated mats lining the ponds, also exhibits a steep gradient increasing with depth, frequently resulting in oxygen supersaturation in the lower depths of certain highly stratified ponds (James et al., 1995; Wait et al., 2006). Photosynthesis, which causes the oxygen supersaturation, increases $\mathrm{pH}$ via the removal of $\mathrm{CO}_{2}$ from the water reducing carbonic acid (Hendriks et al., 2014), both parameters are constrained by the conductivity density gradients, illustrating the interplay between biotic and abiotic variables along physicochemical gradients that occur with depth in these ponds (Wait et al., 2006).

Past studies of Antarctic ponds, and lakes, have provided some insight into how microbial communities are structured in these extreme aquatic environments. These studies primarily focused on the dense microbial mats and sediments lining the ponds (Fernandez-Valiente et al., 2001; Griffin \& Tiedje, 2007) and on the geochemistry of the water column (Matsumoto et al., 1992; De Mora et al., 1994; Wait et al., 2006), with little or no work on the microbiology of the water column itself. Previous research has also been limited by a reliance on microscopic identification of microorganisms, (Vincent \& James, 1996; de los Rios et al., 2004; Sabbe et al., 2004), which suggested these pond ecosystems supported low biodiversity, probably due to the presence of cryptic species. However, more recently, the use of culture-independent molecular genetic tools has 
allowed microbiologists to identify and investigate a more extensive biodiversity in these systems (Vincent \& James, 1996; Brambilla et al., 2001; Sjoling \& Cowan, 2003; Hughes et al., 2006; Cary et al., 2010).

This project is the first in-depth study to characterise the microbial communities in the water column of Bratina Island ponds and to describe their relationship to pond geochemistry. Utilising molecular genetic tools (a combination of DNA fingerprinting and high throughput next-gen sequencing) coupled with geochemistry, five ponds were characterised, resulting in the most stratified pond being selected for higher resolution analysis. These data allowed for the identification of possible geochemical drivers, and the specific bacterial groups they control, within a highly stratified water column.

\section{Materials and methods}

\section{Field sampling strategy}

Water column samples were collected from five separate ponds near Bratina Island $78^{\circ} 01^{\prime} \mathrm{S}$ latitude, $165^{\circ} 32^{\prime} \mathrm{E}$ longitude on the MIS (Fig. 1) shortly after most ponds became ice-free at the beginning of the austral summer in December 2009. Sampled pond depths ranged from 0.3 to $0.5 \mathrm{~m}$ (Supporting Information, Table S1) and sizes from 3 to $20 \mathrm{~m}$ across. Four ponds were ice-free, but a $1-\mathrm{cm}$ surface layer and the middle $25 \%$ of Legin pond was still frozen at this time. A customised micromanipulator/sampling apparatus was constructed (Fig. S1) and used to simultaneously collect physicochemical data (in situ data used to determine sampling frequency) and water samples from the approximate centre of each pond at $2-10 \mathrm{~cm}$ increments $( \pm 1 \mathrm{~mm})$ through a sterilised sampling tube (TYGON $^{\circledR}$ R-3603) that was insulated and capable of mild heating with a nicrome wire heating tape controlled via a rheostat. The tube was flushed with two void volumes (at each depth) before each sample was collected. 8-100 mL of sample was immediately filtered through syringemounted $0.22-\mu \mathrm{m}$ filters (Whatman International Ltd, Kent, UK) until the filter clogged. A small amount of air was pushed through the filter to remove excess water, then gently flooded with a nucleic acid preservative/lysis buffer (CTAB - cetyltrimethylammonium bromide-polyvinylpyrrolidone- $\beta$-mecaptoethanol) (Coyne et al., 2001) and frozen for transport back to the laboratory. Thirteen millilitre of the filtrate was also collected in $15-\mathrm{mL}$ falcon tubes and frozen immediately for later geochemical analysis. Oxygen concentration and temperature were measured in situ using probes attached near the tip of the sampling tube. Oxygen data were collected using a Fibox 3 LCD trace minisensor oxygen metre with data-logger (PreSens Precision sensing, Regensburg, Germany), and temperature data were collected using a Hobo temperature data logger (H09-003-08, Onset Computer Corporation). Finally, a $30 \mathrm{~mL}$ unfiltered sample was collected in a $50-\mathrm{mL}$ falcon tube for immediate $\mathrm{pH}$, and conductivity measurements performed in the field using a SPER Scientific water quality meter (Sper Scientific, Arizona).

\section{Nutrient and elemental analysis}

$\mathrm{NH}_{4}, \mathrm{NO}_{2}$ and $\mathrm{PO}_{4}$ measurements on the filtrate from each sample were carried out at the University of Waikato using an Aquakem 200CD following the manufacturer's instructions (Thermo Fisher Scientific, Waltham). Elemental analysis was performed on each sample by inductively coupled plasma mass spectrometry (ICP-MS) using a Mass Spectrometer ELAN ${ }^{\circledR}$ DRC II (PerkinElmer Inc., Münster, Germany). To prepare samples for ICPMS, $0.22 \mu \mathrm{m}$ prefiltered pond water was diluted 1:50 with Milli-Q water (Millipore, Billerica, MA). Six samples were diluted $1: 1000$ due to excessive salt concentrations. Once diluted, samples were acidified with $2 \% \mathrm{HNO}_{3}$ (Extra pure Nitric Acid, Ajax Finechem, NSW, Australia). Elements analysed were the following: $\mathrm{Li}^{7}, \mathrm{~B}^{10}, \mathrm{Na}^{23}$, $\mathrm{Mg}^{24}, \mathrm{Al}^{27}, \mathrm{~S}^{34}, \mathrm{~K}^{39}, \mathrm{Ca}^{43}, \mathrm{~V}^{51}, \mathrm{Cr}^{52}, \mathrm{Fe}^{54}, \mathrm{Mn}^{55}, \mathrm{Co}^{59}$, $\mathrm{Ni}^{60}, \mathrm{Cu}^{65}, \mathrm{Zn}^{68}, \mathrm{As}^{75}, \mathrm{Se}^{82}, \mathrm{Sr}^{88}, \mathrm{Ag}^{109}, \mathrm{Cd}^{111}, \mathrm{In}^{115}$, $\mathrm{Ba}^{137}, \mathrm{Tl}^{205}, \mathrm{~Pb}^{207}, \mathrm{Bi}^{209}$ and $\mathrm{U}^{238}$ (results of all measurable variables are in Table S1).

\section{DNA extraction of samples}

DNA was extracted from the filtered biomass using a modified CTAB extraction protocol (Campbell et al., 2001). Briefly, the frozen, sealed $0.22-\mu \mathrm{m}$ sample filters were first thawed on ice and then connected to a syringe containing $1 \mathrm{~mL}$ of fresh CTAB. The exposed filter nipple was parafilmed, and the entire assembly incubated in a Ratek Orbital mixer at 150 r.p.m. and $65{ }^{\circ} \mathrm{C}$ for $30 \mathrm{~min}$. The filter assembly was allowed to cool then $0.5 \mathrm{~mL}$ of the CTAB in the syringe was pushed through the filter assembly to evacuate the lysate into an eppendorf tube. An equal volume of chloroform/isoamyl alcohol (24:1) was then added to the lysate and mixed on the orbital mixer at 150 r.p.m. and $65{ }^{\circ} \mathrm{C}$ for a further $30 \mathrm{~min}$. The eppendorf tube was then centrifuged for $15 \mathrm{~min}$ at $16900 \mathrm{~g}$, and the aqueous phase transferred to a new tube. Nucleic acids were precipitated by addition of 1 volume of isopropanol and 0.5 volume of $5 \mathrm{M} \mathrm{NaCl}$ and then incubated at $-80{ }^{\circ} \mathrm{C}$ for at least $1 \mathrm{~h}$. The tube was then centrifuged at $26000 \mathrm{~g}$ for $30 \mathrm{~min}$, and the supernatant discarded, and the DNA pellet washed with $0.5 \mathrm{~mL}$ of $70 \% \mathrm{EtOH}$ and then centrifuged at 15500 r.p.m. for 5 s. The pellet was dried and resuspended in $10-50 \mu \mathrm{L}$ of sterile milliQ $\mathrm{H}_{2} \mathrm{O}$. The extracted 
DNA was quantified using a Nanodrop ND-1000 at 260 nm (NanoDrop Technologies, Montchanin, DE).

\section{Automated ribosomal intergenic spacer analysis (ARISA)}

ARISA DNA fingerprinting (Fisher \& Triplett, 1999) was utilised to resolve bacterial community structure and relative diversity within all ponds, and a comparative subset (Egg, Legin and P70E) was selected to resolve cyanobacterial community structure in Egg pond. From each sample, the bacterial intergenic spacer region (ISR) in the rRNA operon was amplified using PCR. Triplicate $30 \mu \mathrm{L}$ reactions [to reduce stochastic PCR bias (Wintzingerode et al., 1997)] were run for each sample. Bacterial primers used were ITSReub-Hex (5'-GCCAAGGCATCCACC- $3^{\prime}$ ) and ITSF [5'-GTCGTAACAAGGTAGCCGTA-3') (Cardinale et al., 2004)] and the cyanobacterial primers were CY-ARISA-F (5'-GYCAYRCCCGAAGTCRTTAC- $\left.3^{\prime}\right)$ and 23S30R (5'-CHTCGCCTCTGTGTGCCWAGGT-3') (Wood et al., 2008)]. Full PCR components and conditions and quality control procedures are described in Supporting Information.

To visualise, compare and interpret the ARISA fingerprints from different samples, the output was processed with an informatics pipeline (modified from (Abdo et al., 2006) First, all peaks with heights exceeding 250 fluorescence units were accepted as true peaks. The remaining peaks were used to calculate model parameters for a lognormal distribution. Iteratively, peaks with an area exceeding the $99.9 \%$ cumulative distribution of the calculated log-normal distribution for noise were accepted as true peaks. Fragment lengths $<100 \mathrm{bp}$ for bacteria and $150 \mathrm{bp}$ for cyanobacteria were removed from analysis as these were considered to be too small to be ITS fragments (Cardinale et al., 2004; Wood et al., 2008). Peaks were binned into ARISA Fragment Lengths (AFLs) with width $=2 \mathrm{nt}$, and total peak area of each bin was used to calculate relative adundance of each AFL in a given data set. The resulting data matrix was imported into PRIMER 6 for statistical analysis (Clarke \& Gorley, 2006).

In PRIMER 6, peaks were converted to presence/absence data for further analysis, and the number of peaks was totalled from each sample to be used as a proxy for relative alpha diversity (the number of species in a sample). These were subjected to various statistical tests (Spearman's coefficient and Tukey's honest significant difference test) to elucidate relationships between communities. Beta diversity (the comparison of diversity between sites) was investigated using a resemblance matrix created based on the Bray Curtis similarity index (Bray \& Curtis, 1957). From the resemblance matrix, a hierarchical clustering analysis was performed, producing a relational dendrogram. Nonmetric multidimensional scaling (MDS) was performed on the resemblance matrix, which displays relative similarities between communities as distance (i.e. the closer two samples are the more similar community). 2-D MDS plots with a stress value of $<0.2$ were used as they were considered to have accurate information. Information from the dendrogram of the communities was overlaid onto the 2-D MDS plots, which provide percentage similarity levels at 20,40,60 and 80\%, assisting in the evaluation of community structure between samples. ANOSIM analyses and Mantel tests were performed on the resemblance matrix to test specific hypotheses formed from interpretation of MDS plots.

The influence of pond geochemistry on the microbial community was determined using a BEST analysis to find the 'best match' in PRIMER 6. Geochemical data were normalised and a Draftsman plot created to view interrelations between the different variables, so the data could be simplified. Spearman's rank correlation coefficients were then calculated, resulting in a probability $(P)$ of the community differences being explained by the differences in geochemistry. The combination of geochemical variables whose Euclidean distance matrix gave the highest $P$-value were considered the most likely drivers of community dynamics.

\section{4 pyrosequencing}

PCR amplicons containing V5-V6 hypervariable regions of the 16S rRNA gene were utilised to identify specific bacterial community differences in the water column of Egg pond using 454 pyrosequencing. Triplicate $30 \mu \mathrm{L}$ reactions were run for each sample, each reaction containing $0.4 \mu \mathrm{M}$ of each unadapted primer $\mathrm{Tx} 9 \mathrm{~F}$ $\left(5^{\prime}\right.$-GGATTAGAWACCCBGGTAGTC-3 $\left.{ }^{\prime}\right)$ and 1391R (5'-GACGGGCRGTGWGTRCA-3') (Ashby et al., 2007), 1x PCR buffer, $0.2 \mathrm{mM}$ dNTPs, $0.02 \mathrm{mg} \mathrm{mL}^{-1}$ BSA, $0.02 \mathrm{U}$ Platinum Taq, $2 \mathrm{mM} \mathrm{MgCl}_{2}, 20 \mathrm{ng}$ bp genomic DNA, and the reaction was made up to $30 \mu \mathrm{L}$ with milliQ $\mathrm{H}_{2} \mathrm{O}$. Thermal cycling conditions were the following: $94{ }^{\circ} \mathrm{C}$ for $2 \mathrm{~min}$, then 30 cycles of $94^{\circ} \mathrm{C}$ for $20 \mathrm{~s}, 55^{\circ} \mathrm{C}$ for $10 \mathrm{~s}\left(-0.2{ }^{\circ} \mathrm{C}\right.$ per cycle), $72{ }^{\circ} \mathrm{C}$ for $20 \mathrm{~s}$ and a final extension of $72{ }^{\circ} \mathrm{C}$ for $3 \mathrm{~min}$. Once amplified, all triplicate PCRs were combined, run on a $2 \%$ TAE agarose gel stained with 'SYBR Safe' (Invitrogen Ltd) at $80 \mathrm{~V}$, the bands excised and DNA retrieved using the MO BIO UltraClean 15 DNA Purification Kit (MO BIO Laboratories, Carlsbad, CA) as per manufacturer's instructions, but running the final spin step twice. A second round of triplicate PCR was run as above but with only 10 cycles and using $25 \mathrm{ng}$ of the purified DNA from the previous step per reaction (milli-Q $\mathrm{H}_{2} \mathrm{O}$ volume adjusted accordingly). The primers used were adapted for one-way reads 
according to the Roche GS Junior System Guidelines for Amplicon Experimental Design Manual (August 2010), including unique MID identifiers for each sample [BacX-Tx9F (5'-CCATCTCATCCCTGCGTGTCTCCGA CTCAG-MID-GGATTAGAWACCCBGGTAGTC- ${ }^{\prime}{ }^{\prime}$ ) and BacB-1391R (5'-CCTATCCCCTGTGTGCCTTGGCAGTC TCAG-GACGGGCR GTGWGTRCA-3')]. A second gel extraction was performed as above. Samples went through a final cleanup step using the Agencourt AMPure XP system (Beckman Coulter Genomics, Danvers, MA) as per the manufacturer's instructions. A verification gel was run on a $2 \%$ TAE gel to confirm a lack of unwanted bands in the sample. Sample DNA content was quantified using a Qubit Flurometer (Invitrogen Ltd) and was then diluted to $1 \times 10^{9}$ molecules $\mu \mathrm{L}^{-1}$ as per the Roche Amplicon Library Preparation Method Manual [GS Junior Titanium Series, May 2010 (Rev. June 2010)]. QPCR using a KAPA Library Quantification Kit for Roche 454 Titanium/Universal (Kapa Biosystems, Woburn, MA) was used to check the $1 \times 10^{9}$ dilution and was adjusted accordingly for making the amplicon library. The diluted amplicons were mixed together in the desired proportions to create the $1 \times 10^{9}$ amplicon pool. Sequencing was performed using the GS Junior Titanium emPCR Kit (Lib-L), the GS Junior Titanium Sequencing Kit, PicoTiterPlate Kit and GS Junior System according to the manufacturer's instructions (Roche 454 Life Sciences, Branford, CT).

\section{4 pyrosequencing data processing}

454 PCR amplicon pyrosequencing data were first processed using AmpliconNoise v1.0 (Quince et al., 2011). Briefly, raw flowgrams (sff files) with perfectly matching primer and barcode sequences were filtered for a minimum flowgram length of 360 cycles (including primer and barcode sequences) before the first noisy signal (i.e. $0.5-0.7$ or no signal in all four nucleotides). All flowgrams were then truncated at 360 bases and clustered to remove sequencing noise using PyroNoise (Quince et al., 2009, 2011). Noise introduced by PCR was removed using SeqNoise (Quince et al., 2011), and PCR chimeras were removed using Perseus (Quince et al., 2011). The resulting de-replicated sequences were processed using Mothur 1.17.0 (Schloss et al., 2009) to create a unique sequence and names file. Pairwise alignments and distance were calculated using Espirit (Sun et al., 2009). Mothur was then used to cluster sequences into operational taxonomic units (OTUs) defined at the furthest neighbour Jukes-Cantor distance of $0.03\left(\mathrm{OTU}_{0.03}\right)$. Rankabundance data were generated for each sample as well as Venn diagrams and Good's nonparametric coverage estimator was used to evaluate sequencing coverage for each sample. For phylogenetic assignments, representative sequences of all identified $\mathrm{OTU}_{0.03}$ were analysed using the Classifier function provided by the Ribosomal Database Project (RDP) Release 10, Update 15 (Wang et al., 2007). Taxonomic assignment threshold was set at $80 \%$. Phylogenetic analysis of sequences was performed with representative sequences of the top 101 OTUs $_{0.03}(>0.1 \%$ overall abundance in pyrosequencing data sets, representing 12376 reads). Taxonomic trees were constructed using ARB (Ludwig et al., 2004), with DNADIST and neighbour joining analysis. Sequence length ranged from 244 to $392 \mathrm{bp}$, with an average of $384.9 \mathrm{bp}$.

\section{Results}

\section{Physicochemical analysis}

Inter and intrapond physicochemical properties were found to be extremely variable, with dissolved oxygen concentrations from 4.4 to $27.3 \mathrm{ppm}$ (Fig. 3a), conductivity ranging from 0.43 to $110.9 \mathrm{mS} \mathrm{cm}^{-1}$ (Fig. $3 \mathrm{~b}$ ), $\mathrm{pH}$ from 7.3 to 10.1 (Fig. 3c), and temperature from -3.5 to $5.1{ }^{\circ} \mathrm{C}$ (Fig. 3d). A notable geochemical gradient was identified throughout the water column of most ponds. Oxygen concentration varied through the water column, but generally it was highest at the deepest point (increasing from 9.7 at the top to $17.0 \mathrm{ppm}$ in the bottom of Legin). Conductivity was also found to increase with depth in each pond (from $8.2 \mathrm{mS} \mathrm{cm}^{-1}$ at the top to $93.6 \mathrm{mS} \mathrm{cm}{ }^{-1}$ at the bottom of Egg). Although there are significant intrapond variations, the geochemistry MDS analysis (Fig. 2) clearly shows that each pond is geochemically distinct, with Egg forming two distinct clusters.

Egg pond exhibits the most extreme physicochemical stratification observed in this study (Fig. 3a-d). The $\mathrm{pH}$ was stable between 9.4 and 9.5 in the upper $38 \mathrm{~cm}$, dropping to 8.8 at $40 \mathrm{~cm}$ and to 8.1 at the bottom $(48 \mathrm{~cm})$. The drop in $\mathrm{pH}$ corresponds with an increase in conductivity, which rose modestly from $8.2 \mathrm{mS} \mathrm{cm}^{-1}$ at $0 \mathrm{~cm}$ to $10.4 \mathrm{mS} \mathrm{cm}^{-1}$ at $38 \mathrm{~cm}$, with a steep increase between 40 and $46 \mathrm{~cm}$, up to $93.6 \mathrm{mS} \mathrm{cm}^{-1}$ at $48 \mathrm{~cm}$ deep. Dissolved oxygen within Egg increased from $11.5 \mathrm{ppm}$ at the surface, to $17.1 \mathrm{ppm}$ at $36 \mathrm{~cm}$, and $27.3 \mathrm{ppm}$ at $44 \mathrm{~cm}$. The temperature profile was relatively stable, decreasing from $1.6^{\circ} \mathrm{C}$ at the surface to $-1.1{ }^{\circ} \mathrm{C}$ at $46 \mathrm{~cm}$, with a notable increase at the bottom $(48 \mathrm{~cm})$ to $0.6{ }^{\circ} \mathrm{C}$.

$\mathrm{NH}_{4}$ was only detected throughout the water column in Egg and Salt pond (which also have the greatest conductivities) and at the top of Orange and at the bottom of P70E. No $\mathrm{NH}_{4}$ was detected in Legin. $\mathrm{NO}_{2}$ was found at extremely low concentrations in all ponds, except P70E where it was 10 times higher in the upper region (0.032 ppm compared with $0.002 \mathrm{ppm}$ in most other ponds). ICPMS analsis revealed that most resolved 


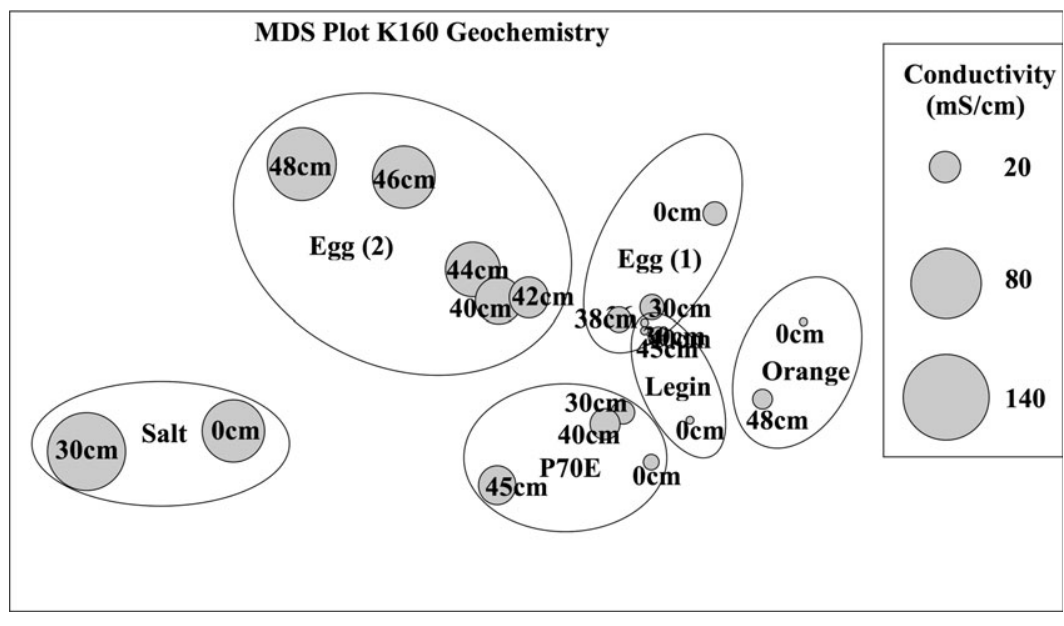

Fig. 2. MDS plot of geochemistry comparing all ponds studied, numbers represent sample depth. The greater the distance between two points, the greater the difference between their geochemistries. Circles surrounding samples represent relative conductivity concentration (the larger the circle the higher the conductivity). MDS plot 2-D stress: 0.08 . Outlining circle used to identify pond clusters. (a)
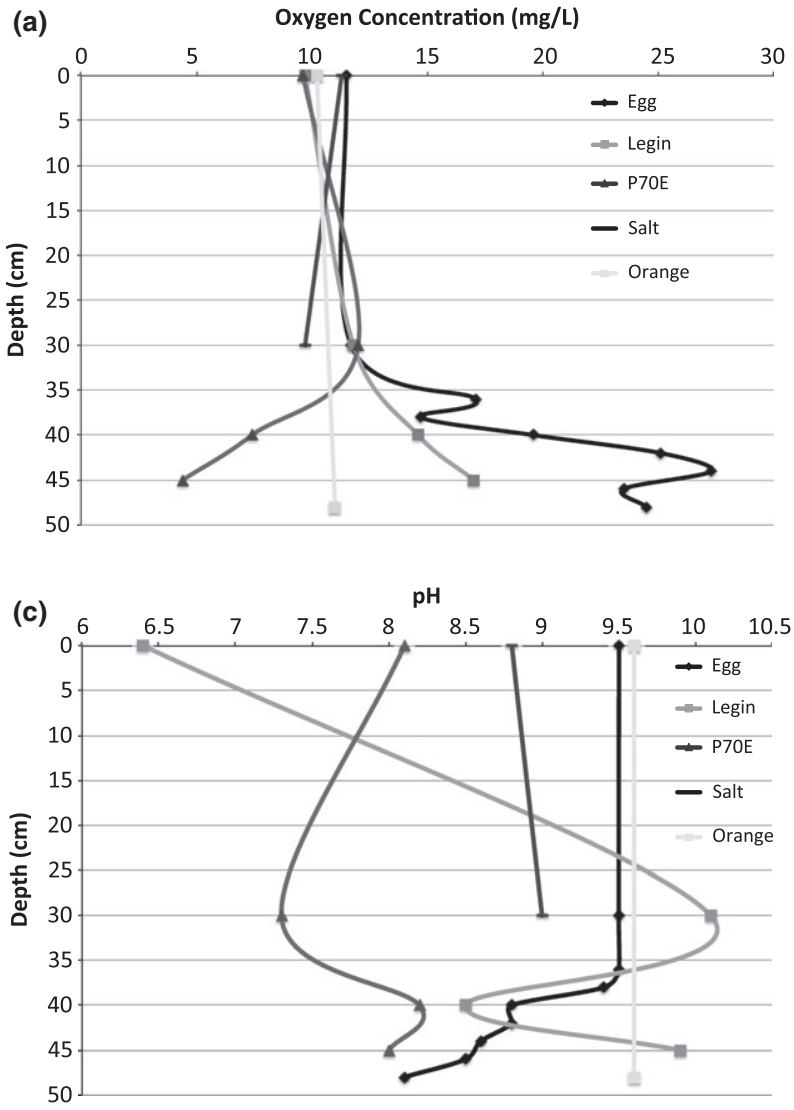

(b)

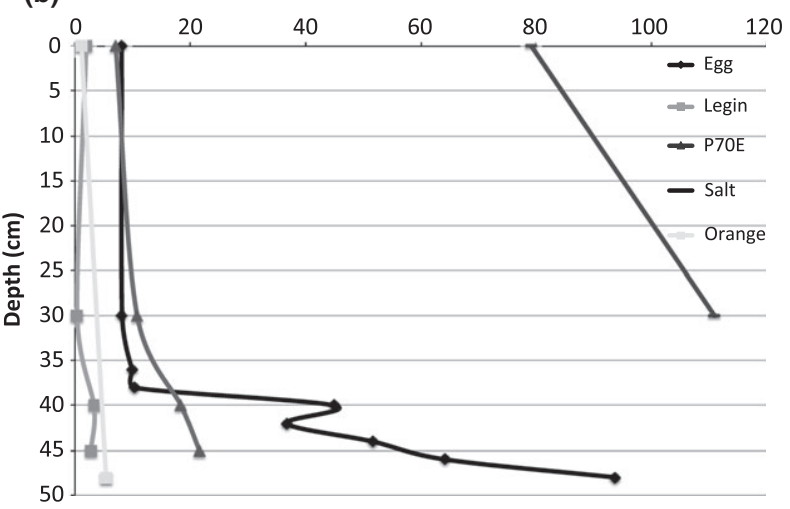

(d)

Temperature (Degrees Celcius)

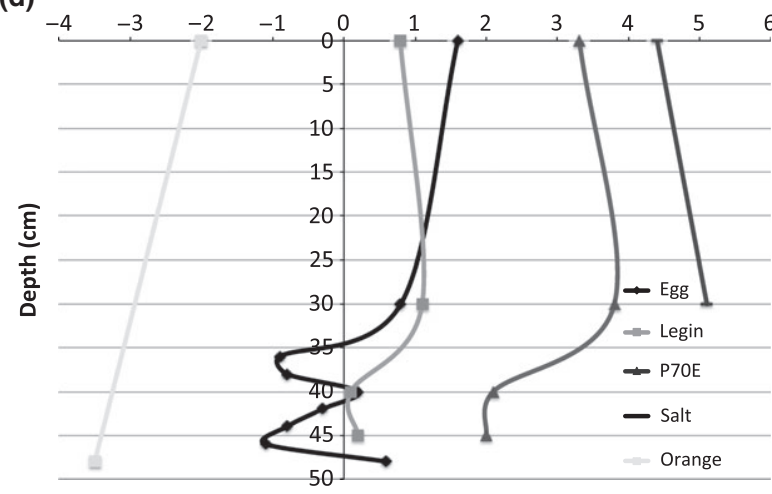

Fig. 3. Geochemistry depth profile showing changes in oxygen concentration (ppm) (a) conductivity $\left(\mathrm{mS} \mathrm{cm}^{-1}\right)(\mathrm{b}), \mathrm{pH}(\mathrm{c})$ and temperature $\left({ }^{\circ} \mathrm{C}\right)(\mathrm{d})$.

elements increased along conductivity gradients, notable observations were that $\mathrm{Co}^{59}$ was only detected in the bottom of Egg $(46-48 \mathrm{~cm})$ and throughout Salt pond. $\mathrm{Ni}^{60}$ was below the detection limit in Legin and Orange and the upper $38 \mathrm{~cm}$ of Egg. Legin also had a significantly reduced amount of $\mathrm{Cu}^{65}$ and $\mathrm{Mn}^{55}$ compared with other ponds, and Orange had a reduced level of $\mathrm{Mn}^{55}$.

\section{DNA fingerprinting}

The number of AFLs was used as a proxy for alpha diversity (Fig. S2). There are no significant differences between alpha diversity of Bacteria from different ponds; however, P70E has significantly higher Cyanobacteria diversity (2939 AFLs per sample compared with a mean of 16.6 over 
all ponds) than Legin and Egg according to Tukey's Honest Significant Difference Test $(P \leq 0.001$ for Egg and $P \leq 0.001$ for Legin). A Spearman's rank correlation coefficient showed no significant correlations between alpha diversity and depth for Bacteria or Cyanobacteria. Lowest diversity occurred in Salt pond (12-25 AFLs) containing the highest overall conductivity of the sample set; however, when removed as an outlier, there was a positive correlation between average conductivity and average bacterial ARISA AFLs but with only a marginal significance $(P=0.04)$.

Beta diversity comparisons were visualised using a 2-D MDS plot for bacterial communities from five different ponds (Fig. 4a) and cyanobacterial communities from three ponds (Fig. 4b). Microbial communities were identified as significantly dissimilar between ponds at $40 \%$

(a) Bacterial community comparison of five Antarctic ponds water columns

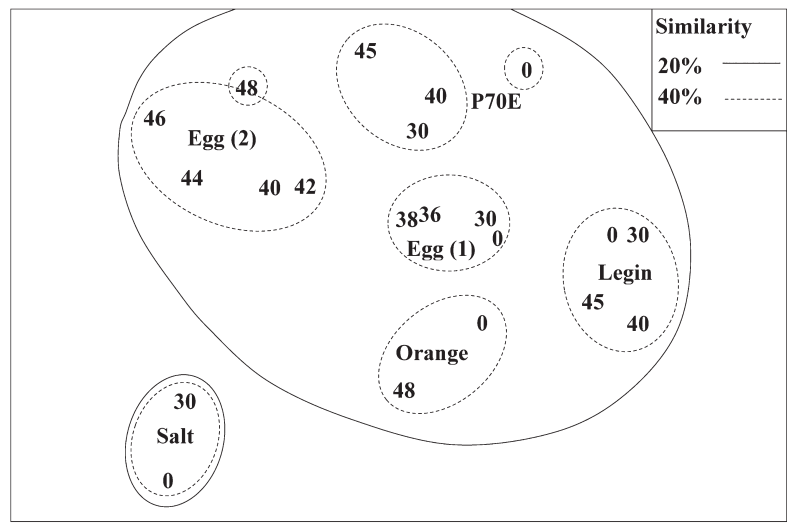

(b)

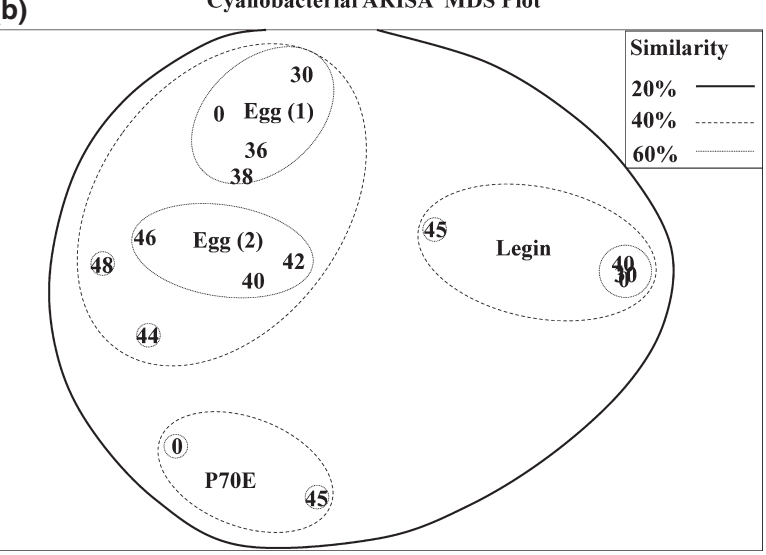

Fig. 4. Bacterial and Cyanobacterial ARISA MDS Plots showing percentage similarities of pond communities (a) bacterial ARISA, data normalised, converted to presence or absence points, and subjected to a Bray Curtis similarity matrix, MDS plot 2-D stress 0.15 . (b) cyanobacterial ARISA, data normalised, converted to presence or absence points, and subjected to a Bray Curtis similarity matrix, MDS plot 2D stress 0.09 . similarity: cyanobacterial ANOSIM $R=0.8605, P=0.001$; bacterial ANOSIM $R=0.766, P=0.001$ (Fig. 4 a and b). P70E and Egg ponds were exceptions to this general observation. In P70E, the bacterial community observed at $0 \mathrm{~cm}$ depth differs from the bacterial communities observed at all other depths (40\% similarity). A Mantel test confirmed that bacterial communities at similar depths in Egg pond were more comparable than those further apart $(R=0.8934, P=0.002)$. Bacterial communities from Egg pond formed two major clusters based on depth; Egg (1), the upper 0-38 cm and Egg (2), the lower depths, 40-48 cm (Fig. 4a), while a similar clustering structure is apparent in cyanobacterial communities at $60 \%$ similarity (Fig. 4b). These observations were reflected in an ANOSIM test for bacterial $(R=0.975$, $P=0.008)$ and cyanobacterial communities $(R=0.4438$, $P=0.026)$. This combined data resulted in the selection of three samples from Egg pond, which represented the greatest variation in community structure down the stratified water column. Bacterial communities from Salt pond stood out as being unique from all other ponds $(20 \%$ similarity).

BEST analysis was used to correlate bacterial and cyanobacterial community structure to differences in geochemical profiles (Table 1), with both appearing to be well correlated to conductivity as a major contributing factor. Conductivity and $\mathrm{Ag}^{109}$ were the best explanatory variables for cyanobacterial communities (Spearman's $\rho=0.662$ ), and temperature, conductivity and $\mathrm{V}^{51}$ were the major explanatory variables for bacterial communities (Spearman's $\rho=0.698$ ). When Egg was analysed on its own, higher probabilities were achieved for community

Table 1. Geochemistry linked to community structure using BEST analysis for cyanobacterial and bacterial DNA fingerprints (ARISA). A Spearman's rank correlation of 1.0 would indicate a $100 \%$ linkage between the variable/s selected and the differences in communities

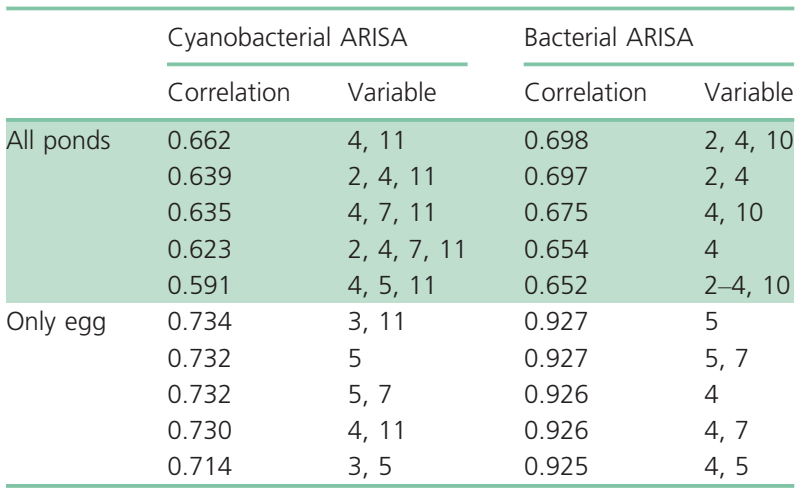

Variable designation: $1=$ depth, $2=$ temperature $(C+10), 3=$ dissolved oxygen (ppm), $4=$ conductivity $\left(\mathrm{mS} \mathrm{cm}^{-1}\right), 5=\mathrm{pH}, 6=$ total phosphate (ppm), $\quad 7=\mathrm{NO}_{2} \quad(\mathrm{ppm}), \quad 8=\mathrm{NH}_{4} \quad(\mathrm{ppm}), \quad 9=\mathrm{Al}^{27}$, $10=\mathrm{V}^{51}, 11=\mathrm{Ag}^{109}$. 
linkages to geochemical variables within Egg. Cyanobacterial communities of Egg appear moderately influenced by $\mathrm{pH}$, which had the highest probability as a single driver of diversity (Spearman's $\rho$ of 0.732). Both $\mathrm{pH}$ and conductivity were determined to be strongly correlated to bacterial diversity differences within Egg (Spearman's $\rho=0.927$ for $\mathrm{pH}$ and $\rho=0.926$ for conductivity).

\section{4 pyrosequencing}

454 pyrosequencing of three representative samples from Egg pond created a data set of 12995 reads that passed quality scoring, which clustered into 583 OTUs at a $97 \%$ sequence identity $\left(\mathrm{OTU}_{0.03} ;\right.$ Fig. 5). Good's nonparametric coverage estimator indicates that sampling coverage was $98.6 \%$ for $0 \mathrm{~cm}, 97.4 \%$ for $40 \mathrm{~cm}$ and $93.5 \%$ for $48 \mathrm{~cm}$. Each sample contained a high number of unique OTUs, the number increasing with depth; however, the percentage of reads represented by sample-specific unique OTUs was $<7 \%$ in the surface and middle $(40 \mathrm{~cm})$ depths and $14.2 \%$ in the bottom $(48 \mathrm{~cm})$ depth. A majority of reads present in the surface (93.1\%) were represented by OTUs present at all depths. A majority of reads in the middle and bottom depths $(83.6 \%$ and $84.2 \%$, respectively) were represented by OTUs shared between those depths, but absent in the surface.

Phylum/class level investigation revealed dramatic shifts in the bacterial communities with depth through the water column of Egg (Fig. 6). At the surface $(0 \mathrm{~cm})$, the community was least diverse, with six phyla well represented. This sample was dominated by Bacteroidetes (68\%), with one OTU contributing $64.8 \%$ [the sequence of this OTU has $100 \%$ identity with Algoriphagus yeomjeoni, isolated from a marine solar saltern (Yoon et al., $2005)]$, and $\beta$-Proteobacteria (18.9\%), with one OTU contributing $18.6 \%$ [which has $100 \%$ sequence identity to Hydrogenophaga taeniospiralis isolated in the Arctic, and to a number of Antarctic lake isolates (VanTrappen et al., 2002)]. At $40 \mathrm{~cm}$, community diversity increased, with 12 phyla including the six seen at the surface. At this depth, the community had also shifted to a $\gamma$-Proteobacteria (66.1\%) dominated community with the reads from one OTU contributing $60.8 \%$ [this OTU has $99 \%$ identity to Psychromonas sp. isolated from Arctic sea ice (Auman et al., 2006)], the Bacteroidetes were again a major phyla but only $10.9 \%$ of the community. In the deepest sample $(48 \mathrm{~cm})$, diversity increased dramatically, with 18 phyla including all those seen in the $40 \mathrm{~cm}$ sample. Again the $\gamma$-Proteobacteria were the dominant phyla $(50.8 \%)$, with one OTU contributing $46.1 \%$ (the same OTU dominant at $40 \mathrm{~cm}$ ), the only other major group were uncharacterised, although this contained only one OTU (16.8\%) with a [96-98\% identity to environmental sequences from a hypersaline microbial mat (Isenbarger et al., 2008)] The Bacteroidetes $(5.6 \%)$ were the third most represented phyla.

\section{Egg0}

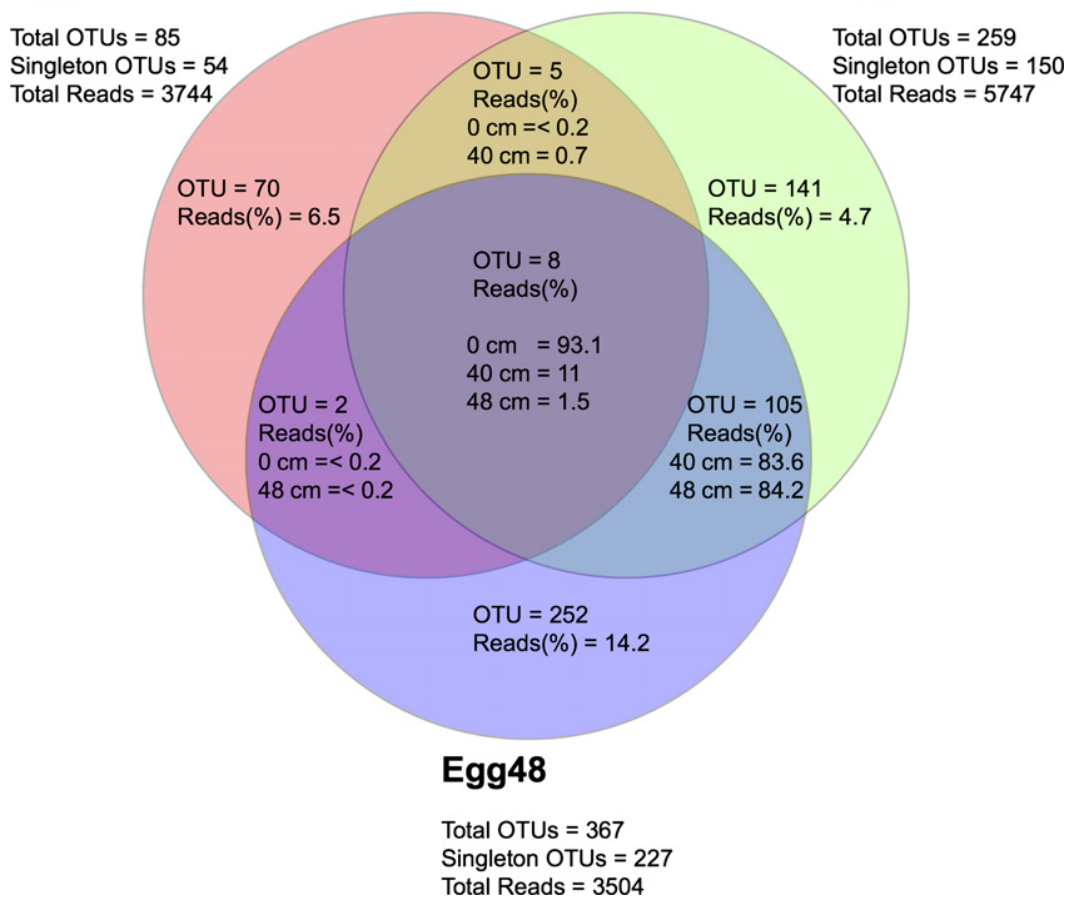

Fig. 5. Summary of 454 sequencing data (at a distance of 0.03 ), and similarities between depths of Egg pond. The total OTU richness of all the groups is 583, and total read number is 12995. 

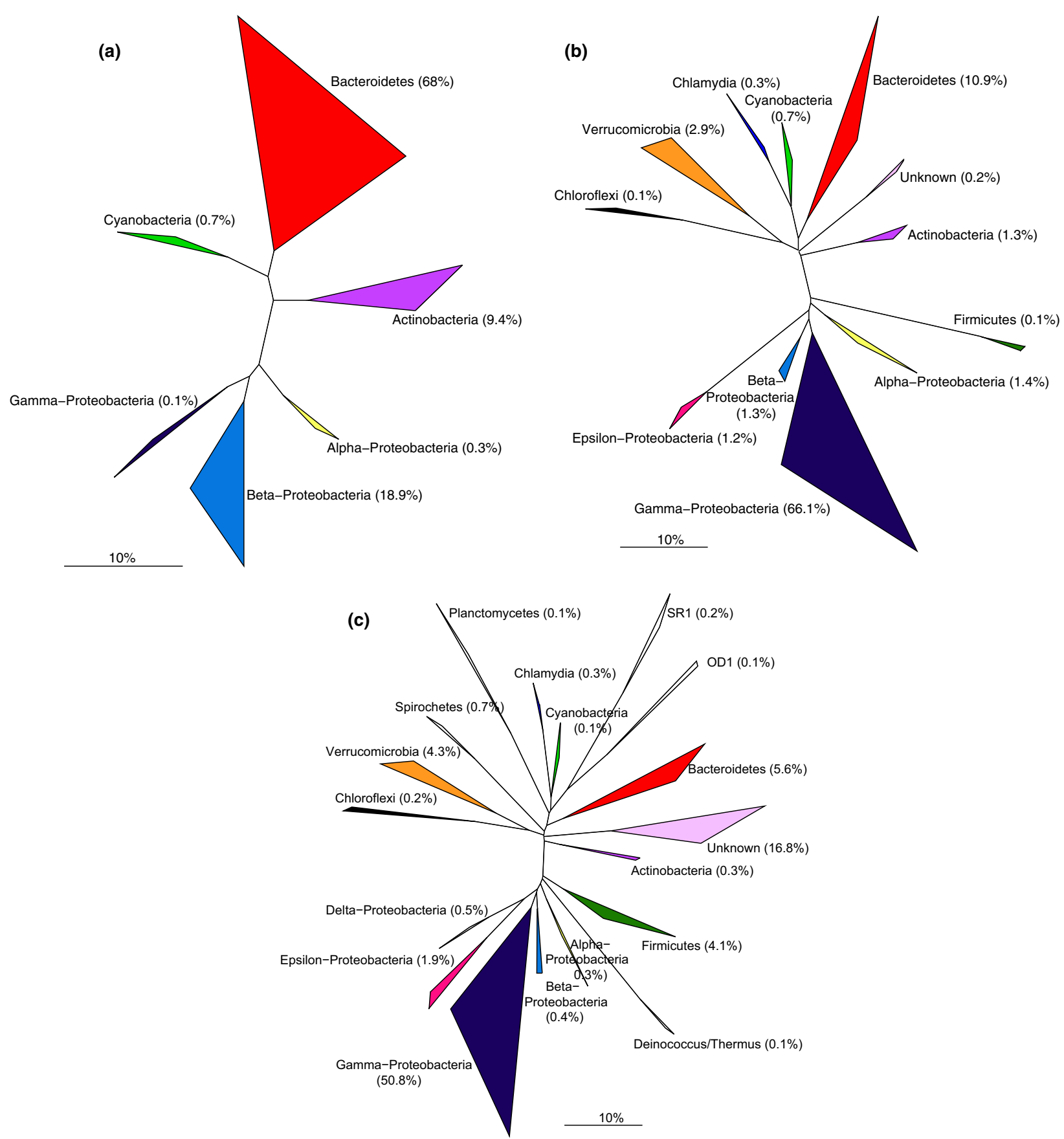

Fig. 6. Phylum-level diversity of bacterial 165 rRNA gene sequences from different depths of Egg pond. Percentage abundance of phyla within each site are shown (in parentheses) for the (a) surface sample, (b) $40 \mathrm{~cm}$ deep sample and (c) $48 \mathrm{~cm}$ deep sample. 454 pyrosequencing reads were denoised and clustered at $97 \%$ (farthest neighbour) to obtain 583 OTUs $_{0.03}$ in total, of which 120 OTUs 0.03 were shared. The top 101 OTUs $_{0.03}$ with $>0.1 \%$ abundance in any sample are used in this analysis.

\section{Discussion}

The focus of this study was to determine whether the unique geochemistry previously reported in the water columns of Bratina ponds supports unique bacterioplankton communities (Matsumoto et al., 1992; Wait et al., 2006; Webster-Brown et al., 2012). Early studies of pond sediments from Bratina meltwater ponds have identified highly diverse (Sjoling \& Cowan, 2003) and variable microbial communities between ponds (Kemp \& Aller, 
2004); however; the environmental factors driving these differences were not determined, and overlying waters were never investigated. Analysis of ARISA fragments in this study has revealed a statistically significant difference (ANOSIM) between pond microbial communities for Bacteria $(R=0.766, P=0.001)$ and Cyanobacteria $(R=0.8605, P=0.001)$. The highly geochemically stratified Egg pond formed two distinct bacterial communities ( $R=0.975, P=0.008)$, with BEST analysis indicating $\mathrm{pH}$ and conductivity as major contributors to community differences along this steep gradient. Pyrosequencing of representative samples from Egg pond identified a diverse community of 583 unique OTUs, which exhibit notably different community structures with depth reinforcing the conclusions based on ARISA results. Although sequencing coverage was not $100 \%$ in any sample for this investigation, this would not affect conclusions formed from this data, only resulting in a slight underestimation of diversity.

The relative beta diversity of Cyanobacteria and Bacteria (ARISA) was generally pond-specific (visualised using a MDS plot, confirmed statistically by ANOSIM). This observation is consistent with microscopic analysis of planktonic communities (James et al., 1995), which classified three groups of ponds based on size, conductivity, and the presence and abundance of various planktonic groups. Each of the three groups included ponds sampled in this study (P70E, Legin and Salt). This suggests that these ponds consistently harbour different geochemical environments and biological communities. The exception to this observation was Egg pond, which formed two depth-related microbial groupings (Fig. 4a, confirmed by ANOSIM) consistent with a steep geochemical gradient of conductivity and $\mathrm{pH}$, both found to be drivers of community shifts in other studies (Sabbe et al., 2004; de Figueiredo et al., 2010).

BEST analysis has previously been successfully utilised to link geochemical variability to variation in biological community profiles from fingerprinting data (Wood et al., 2008; Soo et al., 2009; Smith et al., 2010). In this study, BEST analysis indicated a strong correlation between differences in conductivity contributing to cyanobacterial and bacterial community structure for all five ponds studied. In addition, independent analysis of Egg indicated that both bacterial and cyanobacterial community structure was significantly correlated to differences in $\mathrm{pH}$ and conductivity. The $\mathrm{pH}$ and conductivity in Egg show an inverse relationship to one another, so neither can be singled out as the primary variable responsible for community structure changes; however, both have previously been identified as drivers of community structure in aquatic environments (James et al., 1995; Sabbe et al., 2004; Kaartokallio et al., 2005; de Figueiredo et al., 2010;
Jiang et al., 2010; Laque et al., 2010). Examination of major OTU abundances between depths reinforces conductivity as the dominant driver to community structure. The Genus Hydrogenophaga was identified as a major OTU in the surface sample, decreasing significantly with depth along the increasing conductivity gradient. Several species of this genus have been previously isolated from a number of Arctic and Antarctic environments (Newdell \& Rutter, 1994; VanTrappen et al., 2002) and found to have a maximum $\mathrm{NaCl}$ tolerance of $1 \%$ (Yoon et al., 2008) explaining this observation. Algoriphagus yeomjeoni, previously identified in a cold marine environment and in Antarctic lake mats (Bowman et al., 2003; Van Trappen et al., 2004), has a broader salt tolerance of up to $9 \%$ $\mathrm{NaCl}$ and an optimum of $1 \%$ (Yoon et al., 2005). Its abundance is highest at the surface then decreases significantly with depth; however, it remains at higher concentrations than Hydrogenophaga in the 40 and $48 \mathrm{~cm}$ samples likely due to its greater salt tolerance. The genus Psychromonas, previously isolated from pond sediments at Bratina Island (Mountfort et al., 1998) and Arctic ice (Auman et al., 2006), was dominant at both 40 and $48 \mathrm{~cm}$ and was barely detected at $0 \mathrm{~cm}$, reflective of its ability to grow well between 1 and $10 \% \mathrm{NaCl}$ (Auman et al., 2006). The second most abundant OTU at $48 \mathrm{~cm}$ further reinforces halophilic dominance with depth, sharing a high identity to sequences gained from a hypersaline solar saltern (Isenbarger et al., 2008).

Combinations of $\mathrm{pH}$ and conductivity with temperature, $\mathrm{V}, \mathrm{NO}_{2}, \mathrm{Ag}$ and dissolved oxygen are all highly correlated to microbial community structure. Each identified variable has previously reported to have some influence on planktonic microorganisms. Vanadium can interfere with iron uptake (Baysse et al., 2000); Ag has well-known antimicrobial properties (Throback et al., 2007); nitrogen limitation alters primary productivity in phytoplankton population in these ponds (Sorrell et al., 2013); hypervariation in oxygen concentration with depth selects for zones of aerobic, anaerobic (Bell \& Laybourn-Parry, 1999) and hyperoxic tolerant microorganisms (Fridovich, 1998) and due to variable optimum growth temperatures for microorganisms minor variations in temperature, especially at near-freezing temperatures can dramatically influence community structure (Mountfort et al., 2003). Regardless of biological mechanism, the extent of differences in $\mathrm{V}, \mathrm{Ag}$ and $\mathrm{NO}_{2}$ concentration are well below those found to have biological significance (Yamanaka et al., 2005; Sorrell et al., 2013), and their low correlation scores individually indicate that it is unlikely that any of these variables will strongly influence microbial community structure compared with $\mathrm{pH}$ and conductivity. DO and temperature are capable of influencing community structure; however, they too provide weak correlations 
individually. Interestingly although $\mathrm{PO}_{4}$ is an essential nutrient, it was not identified as a driver of community structure in this analysis. It is likely the interplay between these, and other unknown factors, produces the net effects in the microbial communities.

Pyrosequencing data indicated an increase in diversity with depth in Egg, inconsistant with bacterial ARISA, which showed no significant correlation between diversity and depth (Spearman's rank correlation coefficient). This could be due to the dominance of a few major groups at the surface $(86.9 \%$ for the top two abundant groups compared with $66.8 \%$ at $48 \mathrm{~cm}$ ), while the large number of minor groups seen at the bottom in 454 data could have been below the detection limit for ARISA. The dominance of a few taxa in bacterial communities is not uncommon (Massana et al., 2000; Tyson et al., 2004; Zeng et al., 2013; Laas et al., 2014; Lee et al., 2014) however rarely to this extent. The annual extreme freeze thaw process this pond goes through could skew the community towards bacteria that remain metabolically active over winter or those that could rapidly re-emerge from their inactive states (Foreman et al., 2010). The fact that the dominant OTU at each depth had increasing salt tolerances along the conductivity gradient shows the biological response to increasing selective pressures. A large proportion of reads were shared between the middle and bottom depths but not with the surface sample. The middle depth geochemically represented the beginning of the brine layer, which due to its density would impede direct mixing of the surface waters with the lower layers of the pond (Wait et al., 2006); however, the large proportion of shared OTUs indicates there is mixing within this brine layer or that certain taxa share broader tolerances to transcend these extreme gradients. Due to the dynamic nature of these ponds, over the course of a season many groups are likely to emerge from the rare biosphere to become dominant within a community, only to be outcompeted once again when conditions change.

Both ARISA and 454 data separate the surface (whose dominant phyla is Bacteriodetes), from the $40 \mathrm{~cm}$ and $48 \mathrm{~cm}$ samples (where the dominant phyla is $\gamma$-Proteobacteria). The increase in $\gamma$-Proteobacteria and decrease in Bacteriodetes, with depth correlates to the increase in conductivity and decrease in $\mathrm{pH}$ down the water column. These differences in dominant phyla agree with the BEST analysis, which indicated these two factors were the major cause for community shifts. Although many other minerals associated with the conductivity also differed, none of those elements revealed through ICPMS analysis appeared to be significant drivers of community diversity.

An important consideration in any study of meltwater ponds is that the time of sampling can dramatically influence geochemistry (Matsumoto et al., 1992; James et al.,
1995; Hawes et al., 1999; Wait et al., 2006), which will in turn influence the resident microbiology. Samples for this study were collected early in the summer (early December 2009), so ponds were not at their maximal biological activity compared with those previously collected in January (James et al., 1995; Wait et al., 2006), when ponds would have been melted for longer, were probably warmer and may have undergone greater mixing due to the lack of surface ice and significant summer winds. As the ponds are meltwater fed, the amount of ice and snow input each year is important to the overall soluble ion concentration of the ponds. In 2009, ponds were significantly shallower than in other years, for example, P70E was $0.85 \mathrm{~m}$ deep in January 1992 (James et al., 1995), at least $0.8 \mathrm{~m}$ deep in October 2003 and at least $1 \mathrm{~m}$ deep in January 2004 (Wait et al., 2006), compared with a significantly shallower $0.45 \mathrm{~m}$ in this study. Although differences in meltwater input can rapidly alter geochemical variables during and between seasons (Schmidt et al., 1991; Hitzfeld et al., 2000; Jungblut et al., 2005), comparison with previous work reveals that for a given pond, certain geochemical parameters can remain stable over considerable time scales (De Mora et al., 1994; James et al., 1995; Wait et al., 2006).

\section{Conclusions}

The water column of five Bratina Island meltwater ponds was examined to understand how local geochemistry effects the structure of the resident microbial community, using fine scale biological and geochemical sampling. Biological samples were genotyped using ARISA, which allowed systematic comparison of bacterial and cyanobacterial communities supported in each pond through the entire depth profile. Significant differences between and within pond geochemistry and microbial diversity were detected. Specifically, when examining Egg pond separately from other ponds, clear links between the bacterial and cyanobacterial communities with $\mathrm{pH}$ and conductivity were identified as major variables that appear to influence microbial diversity and community structure. These results were verified by utilising 454 pyrosequencing to identify specific phylum-level differences throughout the water column. This reinforces the belief that geochemistry can be a driver of community structure. However, the microbial communities of a single Bratina Island pond may be found to have individual drivers, different to those of other ponds. This makes these ponds extremely valuable as a scientific resource, as they can be considered to be completely isolated extreme aquatic ecosystems sharing the same climate, but representative of the geochemical diversity of aquatic ecosystems (both ponds and lakes) scattered across the Antarctic continent. 


\section{Acknowledgements}

This Research was funded by New Zealand Post and logistical support was provided by Antarctica New Zealand through their postgraduate research programme (project number K160). Support was also provided by the International Centre for Terrestrial Antarctic Research (ICTAR) at the University of Waikato. We are grateful to Sarah Kelly for assistance with 454 sample preparation and Charles Lee for sequence data processing and other advice during the project.

\section{References}

Abdo Z, Schuette UME, Bent SJ, Williams CJ, Forney LJ \& Joyce P (2006) Statistical methods for characterizing diversity of microbial communities by analysis of terminal restriction fragment length polymorphisms of $16 \mathrm{~S}$ rRNA genes. Environ Microbiol 8: 929-938.

Ashby MN, Rine J, Mongodin EF, Nelson KE \& Dimster-Denk D (2007) Serial analysis of rRNA genes and the unexpected dominance of rare members of microbial communities. Am Soc Microbiol 73: 4532-4542.

Auman AJ, Breezee JL, Gosink JJ, Kampfer P, Staley JT \& Email j (2006) Psychromonas ingrahamii sp. nov., a novel gas vacuolate, psychrophilic bacterium isolated from Arctic polar sea ice. Int J Syst Evol Microbiol 56: 1001-1007.

Baysse C, De Vos D, Naudet Y, Vandermonde A, Ochsner U, Meyer JM, Budzikiewicz H, Schafer M, Fuchs R \& Cornelis P (2000) Vanadium interferes with siderophore-mediated iron uptake in Pseudomonas aeruginosa. Microbiology 146: 2425-2434.

Bell EM \& Laybourn-Parry J (1999) Annual plankton dynamics in an Antarctic saline lake. Freshw Biol 41: 507519.

Bowman JP, Rea SM, McCammon SA \& McMeekin TA (2000) Diversity and community structure within anoxic sediment from marine salinity meromictic lakes and a coastal meromictic marine basin, Vestfold Hills, Eastern Antarctica. Environ Microbiol 2: 227-237.

Bowman JP, Mancuso C, Nichols CM \& Gibson JAE (2003) Algoriphagus ratkowskyi gen. nov., sp. nov., Brumimicrobium glaciale gen. nov., sp. nov., Cryomorpha ignava gen. nov., sp. nov and Crocinitomix catalasitica gen. nov., sp. nov., novel flavobacteria isolated from various polar habitats. Int J Syst Evol Microbiol 53: 1343-1355.

Brambilla E, Hippe H, Hagelstein A, Tindall BJ \& Stackebrandt E (2001) 16S rDNA diversity of cultured and uncultured prokaryotes of a mat sample from Lake Fryxell, McMurdo Dry Valleys, Antarctica. Extremophiles 5: 23-33.

Bray RJ \& Curtis JT (1957) An ordination of the upland forest communities of southern Wisconsin. Ecol Monogr 27: 325349.

Campbell BJ, Jeanthon C, Kostka JE, Luther GW \& Cary SC (2001) Growth and phylogenetic properties of novel bacteria belonging to the epsilon subdivision of the Proteobacteria enriched from Alvinella pompejana and deep-sea hydrothermal vents. Appl Environ Microbiol 67: 4566-4572.

Cardinale M, Brusetti L, Quatrini P, Borin S, Puglia AM, Rizzi A, Zanardini E, Sorlini C, Corselli C \& Daffonchio D (2004) Comparison of different primer sets for use in automated ribosomal intergenic spacer analysis of complex bacterial communities. Appl Environ Microbiol 70: 6147-6156.

Cary SC, McDonald IR, Barrett JE \& Cowan DA (2010) On the rocks: the microbiology of Antarctic Dry Valley soils. Nat Rev Microbiol 8: 129-138.

Clarke KR \& Gorley RN (2006) PRIMER V6: User Manual/ Tutorial. PRIMER-E, Plymouth.

Cowan DA \& Tow LA (2004) Endangered Antarctic environments. Annu Rev Microbiol 58: 649-690.

Coyne KJ, Hutchins DA, Hare CE \& Cary SC (2001) Assessing temporal and spatial variability in Pfiesteria piscicida distributions using molecular probing techniques. Aquat Microb Ecol 24: 275-285.

Craig H, Wharton RA \& McKay CP (1992) Oxygen superstauration in ice-covered Antarctic Lakes - Biological versus physical contributions. Science 255: 318-321.

de Figueiredo DR, Pereira MJ \& Correia A (2010) Seasonal modulation of bacterioplankton community at a temperate eutrophic shallow lake. World J Microbiol Biotechnol 26: 1067-1077.

de los Rios A, Ascaso C, Wierzchos J, Fernandez-Valiente E \& Quesada A (2004) Microstructural characterization of cyanobacterial mats from the McMurdo Ice Shelf, Antarctica. Appl Environ Microbiol 70: 569-580.

De Mora SJ, Whitehead RF \& Gregory M (1994) The chemical-composition of glacial melt water ponds and streams on the McMurdo Ice Shelf, Antarctica. Antarct Sci 6: 17-27.

Fernandez-Valiente E, Quesada A, Howard-Williams C \& Hawes I (2001) N-2-fixation in cyanobacterial mats from ponds on the McMurdo Ice Shelf, Antarctica. Microb Ecol 42: 338-349.

Fisher MM \& Triplett EW (1999) Automated approach for ribosomal intergenic spacer analysis of microbial diversity and its application to freshwater bacterial communities. Appl Environ Microbiol 65: 4630-4636.

Foreman CM, Dieser M, Greenwood M, Cory RM, Laybourn-Parry J, Lisle JT, Jaros C, Miller PL, Chin YP \& McKnight DM (2010) When a habitat freezes solid: microorganisms over-winter within the ice column of a coastal Antarctic lake. FEMS Microbiol Ecol 76: 401-412.

Fridovich I (1998) Oxygen toxicity: a radicle explanation. J Exp Biol 201: 1203-1209.

Gibson JAE, Wilmotte A, Taton A, Van der Vijver B, Beyens L \& Dartnall HJG (2006) Biogeographic trends in Antarctic lake communities. Trends in Antarctic Terrestrial and Limnetic Ecosystems: Antarctica as a Global Indicator, Bergstrom DM (Convey P, \& Huskies HL, eds), pp 71-99. Springer, the Netherlands. 
Griffin BM \& Tiedje JM (2007) Microbial reductive dehalogenation in Antarctic melt pond sediments. Antarct Sci 19: 411-416.

Hawes I, Smith R, Howard-Williams C \& Schwarz AM (1999) Environmental conditions during freezing, and response of microbial mats in ponds of the McMurdo Ice Shelf, Antarctica. Antarct Sci 11: 198-208.

Hendriks IE, Olsen YS, Ramajo L, Basso L, Steckbauer A, Moore TS, Howard J \& Duarte CM (2014) Photosynthetic activity buffers ocean acidification in seagrass meadows. Biogeosciences 11: 333-346.

Hitzfeld BC, Lampert CS, Spaeth N, Mountfort D, Kaspar H \& Dietrich DR (2000) Toxin production in cyanobacterial mats from ponds on the McMurdo Ice Shelf, Antarctica. Toxicon 38: 1731-1748.

Howard-Williams C \& Hawes I (2005) Ecological processes in Antarctic inland waters: interactions between physical processes and the nitrogen cycle. 9th Scar International Biology Symposium, pp. 205-217.

Hughes KA, Bolter P, Ott S \& Convey P (2006) Colonisation processes. Trends in Antarctic Terrestrial and Limnetic Ecosystems: Antarctica as a Global Indicator, Bergstrom DM (Convey P, \& Huskies HL, eds), pp 35-54. Springer, the Netherlands.

Isenbarger A, Finney M, Rios-Velazquez $\mathrm{CH}$, Handelsman J \& Ruvkun G (2008) Miniprimer PCR, a new lens for viewing the microbial world. Appl Environ Microbiol 74: 840-849.

James MR, Pridmore RD \& Cummings VJ (1995) Planktonic communities of melt ponds on the McMurdo ice shelf, Antarctica. Polar Biol 15: 555-567.

Jiang HC, Huang QY, Deng SC, Dong HL \& Yu BS (2010) Planktonic actinobacterial diversity along a salinity gradient of a river and five lakes on the Tibetan Plateau.

Extremophiles 14: 367-376.

Jungblut AD, Hawes I, Mountfort D, Hitzfeld B, Dietrich DR, Burns BP \& Neilan BA (2005) Diversity within cyanobacterial mat communities in variable salinity meltwater ponds of McMurdo Ice Shelf, Antarctica. Environ Microbiol 7: 519-529.

Kaartokallio H, Laamanen M \& Sivonen K (2005) Responses of Baltic Sea ice and open-water natural bacterial communities to salinity change. Appl Environ Microbiol 71: 4364-4371.

Kemp PF \& Aller JY (2004) Bacterial diversity in aquatic and other environments: what $16 \mathrm{~S}$ rDNA libraries can tell us. FEMS Microbiol Ecol 47: 161-177.

Koob DD \& Leister GL (1972) Primary productivity and associated physical, chemical, and biological characteristics of lake Bonney: a perennially ice-covered lake in Antarctica, in Llano, G.A, Antarctic Terrestrial Biology. Antarct Res Ser 20: 51-68.

Laas P, Simm J, Lips I \& Metsis M (2014) Spatial variability of winter bacterioplankton community composition in the Gulf of Finland (the Baltic Sea). J Mar Syst 129: 127-134.

Laque T, Farjalla VF, Rosado AS \& Esteves FA (2010) Spatiotemporal variation of bacterial community composition and possible controlling factors in tropical shallow lagoons. Microb Ecol 59: 819-829.

Laybourn-Parry J, Quayle W \& Henshaw T (2002) The biology and evolution of Antarctic saline lakes in relation to salinity and trophy. Polar Biol 25: 542-552.

Lee Y, Hahm D, Jung Y, Park S, Chun J \& Hong S (2014) Bacterial community of sediments from the Australian-Antarctic ridge. Polar Biol 37: 587-593.

Ludwig W, Strunk O, Westram R et al. (2004) ARB: a software environment for sequence data. Nucleic Acids Res 32: 13631371.

Massana R, DeLong EF \& Pedros-Alio C (2000) A few cosmopolitan phylotypes dominate planktonic archaeal assemblages in widely different oceanic provinces. Appl Environ Microbiol 66: 1777-1787.

Matsumoto GI, Kakaya S, Murayama H, Masuda N, Kawano T, Watanuki K \& Torii T (1992) Geochemical characteristics of Antarctic lakes and ponds. Proc NIPR Symp Polar Biol 5: 125-145.

Mountfort DO, Rainey FA, Burghardt J, Kaspar HF \& Stackebrandt E (1998) Psychromonas antarcticus gen. nov., sp. nov., a new aerotolerant anaerobic, halophilic psychrophile isolated from pond sediment of the McMurdo Ice Shelf, Antarctica. Arch Microbiol 169: 231-238.

Mountfort DO, Kaspar HF, Asher RA \& Sutherland D (2003) Influences of pond geochemistry, temperature, and freeze-thaw on terminal anaerobic processes occurring in sediments of six ponds of the McMurdo Ice Shelf, near Bratina Island, Antarctica. Appl Environ Microbiol 69: 583-592.

Newdell DB \& Rutter M (1994) Influence of temperature on growth-rate and competition between 2 Psychrotolerant Antarctic Bacteria - Low Temperature diminishes affinity for substrate uptake. Appl Environ Microbiol 60: 1984-1992.

Pearce DA, van der Gast CJ, Lawley B \& Ellis-Evans JC (2003) Bacterioplankton community diversity in a maritime Antarctic lake, determined by culture-dependent and culture-independent techniques. FEMS Microbiol Ecol 45: 59-70.

Quince C, Lanzen A, Curtis TP, Davenport RJ, Hall N, Head IM, Read LF \& Sloan WT (2009) Accurate determination of microbial diversity from 454 pyrosequencing data. Nat Methods 6: 639-641.

Quince C, Lanzen A, Davenport RJ \& Turnbaugh PJ (2011) Removing noise from pyrosequenced amplicons. $B M C$ Bioinformatics 12: 38 .

Sabbe K, Hodgson DA, Verleyen E, Taton A, Wilmotte A, Vanhoutte K \& Vyverman W (2004) Salinity, depth and the structure and composition of microbial mats in continental Antarctic lakes. Freshw Biol 49: 296-319.

Schloss PD, Westcott SL, Ryabin T et al. (2009) Introducing mothur: open-source, platform-independent, communitysupported software for describing and comparing microbial communities. Appl Environ Microbiol 75: 7537-7541.

Schmidt S, Moskal W, Demora SJ, Howard-Williams C \& Vincent WF (1991) Limnological properties of Antarctic ponds during winter freezing. Antarct Sci 3: 379-388. 
Sjoling S \& Cowan DA (2003) High 16S rDNA bacterial diversity in glacial meltwater lake sediment, Bratina Island, Antarctica. Extremophiles 7: 275-282.

Smith JL, Barrett JE, Tusnady G, Rejto L \& Cary SC

(2010) Resolving environmental drivers of microbial community structure in Antarctic soils. Antarct Sci 22: 673-680.

Soo RM, Wood SA, Grzymski JJ, McDonald IR \& Cary SC (2009) Microbial biodiversity of thermophilic communities in hot mineral soils of Tramway Ridge, Mount Erebus, Antarctica. Environ Microbiol 11: 715-728.

Sorrell BK, Hawes I \& Safi K (2013) Nitrogen and carbon limitation of planktonic primary production and phytoplankton-bacterioplankton coupling in ponds on the McMurdo Ice Shelf, Antarctica. Environ Res Lett 8: 035043.

Sun LJ, Cai YP, Liu L, Yu FH, Farrell ML, McKendree W \& Farmerie W (2009) ESPRIT: estimating species richness using large collections of $16 \mathrm{~S}$ rRNA pyrosequences. Nucleic Acids Res 37: e76.

Taton A, Grubisic S, Brambilla E, De Wit R \& Wilmotte A (2003) Cyanobacterial diversity in natural and artificial microbial mats of Lake Fryxell (McMurdo dry valleys, Antarctica): a morphological and molecular approach. Appl Environ Microbiol 69: 5157-5169.

Throback I, Johansson M, Rosenquist M, Pell M, Hansson M \& Hallin S (2007) Silver (Ag+) reduces denitrification and induces enrichment of novel nirK genotypes in soil. FEMS Microbiol Lett 270: 189-194.

Tyson GW, Chapman J, Hugenholtz P, Allen EE, Ram RJ, Richardson PM, Solovyev VV, Rubin EM, Rokhsar DS \& Banfield JF (2004) Community structure and metabolism through reconstruction of microbial genomes from the environment. Nature 428: 37-43.

Van Trappen S, Vandecandelaere I, Mergaert J \& Swings J (2004) Algoriphagus antarcticus sp. nov., a novel psychrophile from microbial mats in Antarctic lakes. Int $J$ Syst Evol Microbiol 54: 1969-1973.

VanTrappen S, Mergaert J, Van Eygen S, Dawyndt P, Cnockaert MC \& Swings J (2002) Diversity of 746 heterotrophic bacteria isolated from microbial mats from ten Antarctic lakes. Syst Appl Microbiol 25: 603-610.

Vincent WF \& James MR (1996) Biodiversity in extreme aquatic environments: lakes, ponds and streams of the Ross Sea Sector, Antarctica. Biodivers Conserv 5: 1451-1471.

Wait BR, Webster-Brown JG, Brown KL, Healy M \& Hawes I (2006) Chemistry and stratification of Antarctic meltwater ponds I: coastal ponds near Bratina Island, McMurdo Ice Shelf. Antarct Sci 18: 515-524.

Wang Q, Garrity GM, Tiedje JM \& Cole JR (2007) Naive Bayesian classifier for rapid assignment of rRNA sequences into the new bacterial taxonomy. Appl Environ Microbiol 73: 5261-5267.

Webster-Brown J, Hawes I, Safi K, Sorrell B \& Wilson N (2012) Summer-winter transitions in Antarctic ponds: III. Chemical changes. Antarct Sci 24: 121-130.

Wintzingerode F, Gobel UB \& Stackebrandt E (1997) Determination of microbial diversity in environmental samples: pitfalls of PCR-based rRNA analysis. FEMS Microbiol Rev 21: 213-229.

Wood SA, Rueckert A, Cowan DA \& Cary SC (2008) Sources of edaphic cyanobacterial diversity in the Dry Valleys of Eastern Antarctica. ISME J 2: 308-320.

Yamanaka M, Hara K \& Kudo J (2005) Bactericidal actions of a silver ion solution on Escherichia coli, studied by energy-filtering transmission electron microscopy and proteomic analysis. Appl Environ Microbiol 71: 7589-7593.

Yoon JH, Kang SJ, Jung SY, Lee CH, Oh TK \& Email J (2005) Algoriphagus yeomjeoni sp. nov., isolated from a marine solar saltern in the Yellow Sea, Korea. Int J Syst Evol Microbiol 55: 865-870.

Yoon J, Kang S, Ryu S, Jeon C \& Oh T (2008) Hydrogenophaga bisanensis sp. nov., isolated from wastewater of a textile dye works. Int J Syst Evol Microbiol 58: 393-397.

Zeng Y, Zhang F, He J, Lee S, Qiao Z, Yu Y \& Li H (2013) Bacterioplankton community structure in the Arctic waters as revealed by pyrosequencing of $16 \mathrm{~S}$ rRNA genes. Antonie Van Leeuwenhoek 103: 1309-1319.

\section{Supporting Information}

Additional Supporting Information may be found in the online version of this article:

Fig. S1. Diagram showing equipment used to obtain central pond water column samples.

Fig. S2. Summary of bacterial and Cyanobacterial ARISA fragment lengths (AFL) number from each pond sample.

Table S1. Summary geochemistry from Bratina Island ponds December 2009.

Data S1. Automated Ribosomal Intergenic Spacer Analysis (ARISA). 